\title{
COLLECTIVE BARGAINING MISJUDGED: THE MARIKANA MASSACRE ${ }^{1}$
}

\author{
Saul Porsche Makama \\ $B A$ LLB LLM \\ Senior Lecturer, Public Constitutional and \\ International Law, University of South Africa \\ Lux Lesley Kwena Kubjana \\ LLB LLM \\ Senior Lecturer, Mercantile Law, University of \\ South Africa
}

\section{SUMMARY}

The tradition of violence during collective bargaining processes in South Africa (particularly during a strike) can be traced back to the colonial period, where the struggle for better employment terms and conditions was conflated with the struggle for freedom from political oppression, apartheid and the colonial regime. An example in this regard is the Sharpeville uprising. In this case, the State's reaction to the uprising was to call upon the armed forces to quell the situation, and in the process, lives and limbs were lost; nobody was held accountable for this. This was surely a bad legacy to leave for modern times! However, fifty-two years later, South Africa experienced a déja vu moment in the form of the Marikana massacre, which was also chillingly reminiscent of the massacre by apartheid police at Sharpeville in 1960. The writing of this article is informed by the need to avoid another Marikana massacre. The authors bemoan the manner in which this tragic event was handled and argue that, with the right attitude and the right application of resources, the massacre could have been avoided. The authors also lament the approach employed in dealing with the aftermath of the Marikana massacre and conclude that the status quo gives credence to the saying that "an apple does not fall far from the tree". The prosecution of the perpetrators is delayed, no compensation is given to bereft families, and it remains to be seen who was at fault, even after a "good-for-nothing" yet costly Commission of Inquiry ${ }^{2}$ has completed its task.

\footnotetext{
Marikana is a mining town near Rustenburg, in the North West Province of South Africa.

2 The Marikana Commission of Inquiry, chaired by retired Judge Farlam per Proc 50 of 2012 in GG 35680 of 2012-09-12 (the Farlam Commission of Inquiry).
} 


\section{$1 \quad$ INTRODUCTION}

The Marikana incident will remain etched in the minds of many as either a "wrong-turn moment" or a collective bargaining re-invention in the history of collective labour law in South Africa, just as the Sharpeville massacre and the 16 June 1976 uprisings do in the political arena. ${ }^{3}$ The common feature of these two phases is that people wanted to be freed from the unfavourable and exploitative living conditions imposed by the government. Their efforts were met by a committed and formidable police force that claimed lives. Interestingly, the Marikana tragedy happened in the year democratic South Africa came of age - it had recently celebrated its eighteenth birthday. ${ }^{4}$ Worst of all, it did not seem important for the democratic government to look into the reasonableness of mineworkers' demand, in line with one of the general purposes of labour laws and a constitutional imperative - namely, the advancement of social justice. ${ }^{5}$ The authors give context to the concept "social justice" insofar as it connects to and forms part of the demands of the mineworkers. The article adopts the viewpoint that, in general and by design,

3 The Sharpeville massacre occurred on 21 March 1960 at the police station in the South African township of Sharpeville, Transvaal. After a day of demonstrations against pass laws, a crowd of between 5000 and 7000 Black protesters went to the police station. The South African Police opened fire on the crowd, killing 69 people. On 16 June 1976, an uprising that began in Soweto and spread throughout South Africa changed the country's sociopolitical landscape. The events were rooted in apartheid policies that resulted in the introduction of the Bantu Education Act in 1953. The rise of the Black Consciousness Movement (BCM) and the formation of the South African Students Organisation (SASO) raised the political consciousness of many students while others joined the wave of antiapartheid sentiment within the student community. When the language of Afrikaans, alongside English, was made compulsory as a medium of instruction in schools in 1974, Black students began mobilising. On 16 June 1976, between 3000 and 10000 students, mobilised by the South African Students Movements Action Committee and supported by the $\mathrm{BCM}$, marched peacefully to demonstrate and protest against the government's directive. The march was meant to culminate in a rally at Orlando Stadium. On the way, heavily armed police met the students. They fired teargas and later live ammunition. The media revealed the brutality to the world, which resulted in an international outcry. Images of the police firing on peacefully demonstrating students led to international revulsion against South Africa (South African History Online "The June 16 Soweto Youth Uprising" http://www.sahistory.org.za/topic/june-16-soweto-youth-uprising). See also Chetty "The Marikana Massacre: Insurgency and Counter-Insurgency in South Africa" 2016 25(2) New Labour Forum 6269.

4 August 2012. South Africa became a democratic country in 1994.

$5 \mathrm{~S} 1$ of the LRA provides that one of the purposes of the Act is to advance social justice; see also Government of the Republic of South Africa v Grootboom 2001 (1) SA 46; 2000 (11) BCLR 1169 par 1; South African Transport and Allied Workers Union (SATAWU) v Moloto NO 2012 (6) SA 249 (CC); 2012 (11) BCLR 1177 (CC); [2012] 12 BLLR 1193 (CC); (2012) 33 ILJ 2549 (CC) par 21. See also Alexander "Marikana, Turning Point in South African History" 2013 40(138) Review of African Political Economy 605-619 607 where the latter describes the working conditions in Lonmin in the following terms: "the working conditions were dangerous, with risks intensified by pressure to work in hazardous locations; the arduous character of work, which often, because of production targets, included shifts lasting 12 hours or more; doubled-up bodies endlessly shaken by heavy drills; artificial air full of dust and chemicals; high levels of sickness, including TB; and managers who were disrespectful and adversarial. In many cases, workers were caught in a debt trap, leading to forced deductions from wages and payments to micro lenders and lawyers, which resulted in some workers paying 15 times the value of their original loan." 
mineworkers in South Africa do not enjoy the benefits of social justice. They are low-income employees and their safety is a serious concern.

On the day of the massacre, employees were simply asserting a demand that sought to free mineworkers from the plight to which they were subjected over the years by mining houses, aided and abetted by the government, which successfully played the role of a middleman. ${ }^{6}$ The posture and tone of some of the government leaders in the build-up to the Marikana massacre raises serious concerns. Chetty captured this well when she quoted a senior government leader, the Deputy Minister of Safety and Security, as saying to the police, prior to the Marikana massacre: "You must kill the bastards if they threaten you or your community. You must not worry about the regulations. That is my responsibility." ${ }^{7}$ Chetty also reminds us that the same government had made a deal with mining houses in 1994 to improve the conditions of mineworkers. ${ }^{8}$ In such circumstances, the government should rise above any possible self-interest in order to protect both parties, rather than to take sides as it did. The posture taken by the government seeks to undermine the synergy between mining houses and mineworkers in the mining industry. The authors' view is that the mining industry would not exist without mineworkers. The purpose of this article is to provide a critical analysis of the way in which the Marikana saga was handled from the beginning - that is, the efforts taken to control the situation, the police's defence of their actions, and the subsequent measures adopted to try and uncover the truth, in order to establish liability. The authors also express their disappointment that, to date (seven or more years later), no action has been taken despite the revelations contained in the report compiled by the Farlam Commission of Inquiry. ${ }^{9}$ The authors also provide comments about the revelations made in the report, and suggest that legal issues should, in principle, be resolved legally.

The date of 16 August 2012 will, undeniably in the authors' view, go down in the history of the labour relations regime of South Africa and the people in the mining sector in particular, not only as the day that things went horribly wrong, but also the day that they were made to go wrong. On this day, lives of mineworkers were lost simply because they demanded better working conditions $^{10}$ - that is, engaging in an act (collective bargaining) that is protected in terms of the Constitution, ${ }^{11}$ the Labour Relations Act $^{12}$ and

6 Chetty 2016 New Labour Forum 63.

Chetty 2016 New Labour Forum 66.

Ibid.

Marikana Commission of Inquiry Report on Matters of Public, National and International Concern Arising out of the Tragic Incidents at the Lonmin Mine in Marikana, in the North West Province (31 March 2015) (the Marikana Report).

10 Thirty-four were killed and about 70 injured at the hands of the South African Police Services (SAPS).

11 S 23 of the Constitution of the Republic of South Africa, 1996 (the Constitution).

12 S 4 read with s 64 of the Labour Relations Act 66 of 1995 (LRA). The purpose statement, captured in $\mathrm{s} 1$ of the LRA provides for collective bargaining to be used as a vehicle to advance social justice. 
international law. ${ }^{13}$ It is common cause that employees shot at during the Marikana massacre were engaged in a collective bargaining process. Collective bargaining is a recognised form of regulating employment relations between employer and employee. ${ }^{14}$ In this case, Marikana employees demanded a pay increase to secure minimum monthly wages of R12 500 from Lonmin, their employer, by means of strike action. Strike action is a component of collective bargaining sanctioned by the law. ${ }^{15}$ Naturally, a strike involves employees' refusal to work. ${ }^{16}$ This is exactly what happened in Marikana; mineworkers refused to offer normal services to the employer until their demand was met. Mineworkers were exercising their constitutional right to strike. Making an observation about the importance of a strike in the collective bargaining process, Ngcobo $\mathrm{J}$ noted that a strike is to the process of collective bargaining what an engine is to a vehicle. ${ }^{17}$ In the prior case before the LAC, the court held that without a strike, collective bargaining becomes collective begging. ${ }^{18}$ These observations show how central a strike is to the process of collective bargaining. A long-standing labour relations principle is that once the employer and trade union choose bargaining to solve a labour dispute, it becomes a case of an economic power play between the two. ${ }^{19}$

However, on the day under discussion, fully uniformed and heavily armed South African Police Services (SAPS) members were called upon openly to shoot and kill the protesting mineworkers, resulting in the Marikana massacre. ${ }^{20}$ Soon after this event, the National Police Commissioner made an astonishing remark, commending the police for their good work, and thereby, in the authors' view, trying to exonerate the police's "blind

13 The ILO's Right to Organise and Collective Bargaining Convention, 1949. South Africa has ratified this convention in 1996. In terms of this convention, member states should not hamper the freedom of collective bargaining. See also Du Toit, Godfrey, Cooper, Giles, Cohen, Conradie and Steenkamp Labour Relations Law: A Comprehensive Guide (2015) 280 and 281.

14 S 23(5) of the Constitution; Du Toit et al Labour Relations Law: A Comprehensive Guide 277.

$15 \mathrm{~S} 23(1)(c)$ of the Constitution and s 64 of the LRA.

16 See the definition of a strike in terms of $s 213$ of the LRA.

17 National Union of Metal Workers of South Africa v Bader Bop (Pty) Ltd 2003 (2) BCLR 182; 2003 (3) SA 513 (CC); [2003] 2 BLLR 103 (CC) 67.

18 Bader Bop (Pty) Ltd v National Union of Metal and Allied Workers of SA (2002) 23 ILJ 104 (LAC) par 11.

19 Du Toit et al Labour Relations Law: A Comprehensive Guide 277; Jordaan "Collective Bargaining Under the New Labour Relations Act: The Resurrection of Freedom to Contract" http://www.saflii.org/za/journals/LDD/1997/2.pdf (accessed 2018-06-06) 4; Afrox Ltd v SA Chemical Workers Union (1997) 18 ILJ 406 (LC) 410D-E; South African Transport and Allied Workers Union (SATAWU) v Moloto NO supra par 56; s 68(1) of the LRA read with the Code of Good Practice: Dismissal in Schedule 8; Patil Collective Bargaining: Perspective and Practices (1993) 8.

20 Chinguno "Unpacking the Marikana Massacre" (2013) column.global-labouruniversity.org/2013/02/unpacking-marikana-massacre.html (accessed 2018-03-08) 2; Boettger and Rathbone "The Marikana Massacre, Labour and Capitalism: Towards a Ricoeurian Alternative" http://www.koersjournal.org.za/index.php/koers/article/view/2263/pdf (accessed 2018-06-06) 2. 
obedience" to the officials' orders. ${ }^{21}$ Indeed, and as a matter of principle, in every organisation, decisions are taken from the top and escalated down for implementation by so-called subordinates; in the case of Marikana, the subordinates were the police. In light of this, urgent questions arise. Should subordinates be so blind as to do everything that the top says? Should our police act like "hired guns"? These questions are answered later in the discussion.

It is argued that the involvement of the heavily armed SAPS members was not only an unnecessary and unprecedented move for labour relations in the democratic South Africa, but was also a clear indication that police were in a "war mode". ${ }^{22}$ In addition, the presence of police mortuary vehicles at the scene prior to the shooting adds an interesting dimension to the equation - particularly with reference to the mindset of the police on the day:23 strangely, no arrangements were made for an ambulance. ${ }^{24}$ These facts, collectively viewed, give credence to our argument that the Marikana massacre was a premeditated execution.

As already mentioned, the weapon of a strike is sanctioned by the LRA for use by employees to achieve the fundamental ideals set out in the LRA. A strike by employees, whether protected or not, is to date not a criminal offence in South Africa. Therefore, the use of lethal force, as happened in Marikana, contradicts the LRA ideals. It suppresses the weak and the exposed - in this case, the mineworkers, who earned extremely low wages for their immeasurably hard work. Resorting to strike action was the only way to register their discontent. It should be noted that collective bargaining processes in South Africa are regulated in terms of the LRA. Nowhere do the LRA provisions require the use of police force to give effect to the purposes of the Act.

In essence, the Marikana massacre violated the following rights: the victims' right to life, ${ }^{25}$ their right to freedom and security of their persons, ${ }^{26}$ their right not to be subjected to slavery ${ }^{27}$ the right of their families to dignity, and the victims' right to attain decent work. For the purposes of this article,

21 S 199(6) of the Constitution of South Africa provides that no member of any security service may obey a manifestly illegal order.

22 In terms of the Resolution 25/38 taken by the United Nations Human Right Council, namely the Promotion and Protection of Human Rights in the Context of Peaceful Protests, the use of excessive or indiscriminate force is prohibited and, further, lethal force cannot be used merely to disperse a gathering (see www.ohchr.org/Documents/lssues/Executions/A-HRC RES-25-38.pdf (accessed 2019-06-20) 1 and 2).

23 The Marikana Report at 194, 342 and 361.

24 Chetty 2016 New Labour Forum 67.

25 S v Mankwanyane 1995 (3) SA 391 CC; s 11 of the Constitution of the Republic of South Africa, 1996

$26 \mathrm{~S} 12$ of the Constitution.

27 S 13 of the Constitution. The word "slave labour" is defined in Hornby Oxford Advanced Learner's Dictionary of Current English (2000) as work that is very hard and very badly paid. See also an article published online by South African History Online "History of Slavery and Early Colonisation in South Africa", which states, "Today, the term slavery is used to indicate a wide range of human rights abuses and exploitative labour practices" http://www.sahistory.org.za/article/history-slavery-and-early-colonisation-south-africa (accessed 2019-06-17). 
the concept of decent work is also briefly touched on, in order to give context to its connectedness to the dignity of workers, as the authors believe that it was the foundation of this eventful strike.

Decent work, as Somavia observes, is productive work in which rights are protected, and adequate income and social protection are generated.28 "Decent work" is a globally accepted goal through which people's lives can be improved. ${ }^{29}$ Underlying this ideal is a commitment to creating a socially inclusive economy, as aspired to by the International Labour Organisation (ILO), to which South Africa is party. Therefore, the killing that occurred in Marikana amounts to suppression of the employees' right to uplift their lives. This is reminiscent of the 1922 revolt/rebellion, or its re-incarnation in the democratic context. ${ }^{30}$

Collective bargaining naturally entails employees withdrawing their labour if negotiations fail, and effectively forfeiting their wages ${ }^{31}$ while causing the employer to lose the profit and production of the days lost to the strike. The potential loss of production on the part of the employer and of wages on the part of the employees provide a necessary impetus for parties to make the necessary concessions in order to avoid or mitigate the twofold effects of the strike. This whole process is called collective bargaining, which is discussed below. A strike is a fundamental weapon for use by employees against the mighty employer. ${ }^{32}$ Therefore, if need be, it can be resorted to without fear of employer, police or state victimisation. ${ }^{33}$

Furthermore, it could never have been intended by the struggle of the National Democratic Revolution (NDR) ${ }^{34}$ for the government to use the

28 "The Decent Work Agenda in Africa: 2007-2015: Eleventh African Regional meeting Addis Ababa: Report of the Director-General" https://www.ilo.org/public/english/standards/ relm/rgmeet/11afrm/dg-thematic.pdf (accessed 2019-07-12) 15 par 52.

29 Ibid.

30 The Rand Rebellion of 1922 was an armed uprising, also referred to as the Rand Revolt or Red Revolt, which occurred during a period of economic depression following World War I. After the war, mining companies were faced with rising costs and a fall in the price of gold. A general strike was organised by white trade unions in Johannesburg, South Africa, in 1922. This was in response to intensified exploitation of the miners and a decision by goldmining industry leaders to replace many white workers with black workers.

31 It should be noted that one of the principles of a strike in the South African labour relations regime is the principle of "no work, no pay". This means that the employer is not obliged to pay the employees who are involved in a strike, regardless of whether or not the strike is protected.

32 Slabbert, Prinsloo and Bekker Managing Industrial Relations in South Africa (1990) 4-16; Martin, Keaveny and Allen Readings and Cases in Labour Relations and Collective Bargaining (1985) 98-99; Perrins Trade Union Law (1985) 30 and 33. See also Sayles Behavior of Industrial Work Groups: Predication and Control (1958) 56-57 and Forrest The Metal That Will Not Bend: National Union of Metalworkers of South Africa 1980-1995 (2011) 481; Glassman and Cummings Industrial Relations: A Multidimensional View (1985) 165-166.

33 Fawu v Pets Products (Pty) Ltd [2000] 7 BLLR 781 (LC). In this case, the employer had given non-striking employees a R200.00 voucher as a reward for not joining the strike, which the court found to be in contravention of $s 5(3)$ of the LRA. See also NUM $V$ Namakwa Sands [2008] 7 BLLR 675 (LC).

34 The main goals of the South African Communist Party, as described in its 1984 Constitution, is to liberate "the African people in particular, and the black people in general, the destruction of the economic and political power of the racist ruling class, and the 
State's apparatus to suppress employees from exercising their democratic right to engage and participate in the collective bargaining process, thereby rendering it, in Zondo J's observation, "collective begging". ${ }^{35}$ Meanwhile, the former Secretary-General of the Congress of Trade Unions of South Africa, (COSATU), Mr Zwelinzima Vavi, warned, "freedom without addressing the social conditions of our people is hollow". ${ }^{36}$

The social conditions of those killed in Marikana deteriorated even under the government that, at least in its rhetoric, claimed to be on the side of the same workers or equity. It is the miners' argument that at the time of Marikana massacre, they earned as a take-home, a paltry R3 $000-4000.00$ a month in 2012, whilst executives at the same mine would take home R1.2 million. ${ }^{37}$ The National Union of Mineworkers (NUM), as the collective representative, was alive to this reality.

In direct response to the massacre, the government of the Republic of South Africa established a Judicial Commission of Inquiry, chaired by former Supreme Court of Appeal judge lan Gordon Farlam, ${ }^{38}$ whose investigatory role, like a dog on a leash, was restricted by the (heavily criticised) investigation guidelines that were the terms of reference. ${ }^{39} \mathrm{It}$ is the authors' view that the investigation was not, from the time of its inception, meant to uncover the whole truth, but only the selected aspects sanctioned by the terms of reference, thereby rendering all the efforts an unnecessary exercise. Instead, criminal and civil processes would have been appropriate measures, and would have delivered social justice as a value recognised and aspired to in terms of the Constitution ${ }^{40}$ and the labour laws. ${ }^{41}$

establishment of one united state of people's power in which the working class will be the dominant force and which will move uninterruptedly towards social emancipation and the total abolition of exploitation of man by man." (see Slovo "The South African Working Class and the National Democratic Revolution" (1988) https://www.marxists.org/subject/africa/slovo/1988/national-democratic-revolution.htm (accessed 2019-06-17).

35 Bader Bop (Pty) Ltd v National Union of Metal and Allied Workers of SA (JA50/00) [2001] ZALAC 27 (29 November 2001) par 11.

36 Speech by Zwelinzima Vavi (15-12-2006) http://www.polity.org.za/article/zwelinzima-vavisaddress-to-the-young-communist-league-national-congress-15122006; Finnemore Introduction to Labour Relations in South Africa (2013) 127.

37 Dyveke Styve From Marikana to London: The Anti-Blackness of Mining Finance (Thesis for the degree of Philosophiae Doctor, University of Bergen, Norway) 201942 https://bora.uib.no/bora-xmlui/bitstream/handle/1956/20832/Maria\%20Dyveke\%20Styve\% 20v2_Elektronisk.pdf?sequence=1\&isAllowed=y (accessed 2021-03-12).

38 Farlam Commission of Inquiry.

39 The desktop definition of the word "terms of reference" is the scope and limitations of an activity or area of knowledge. See also Collins Advanced English Dictionary, which defines "terms of reference" as the instructions given to someone when they are asked to consider or investigate a particular subject, telling them what they must deal with and what they should ignore. See Anstey "Marikana - And the Push for a New South African Pact" 2013 37(2) SALJ 133

40 Preamble of the Constitution, which reads: "We, the people of South Africa, Recognise the injustices of the past; Honour those who suffered for justice and freedom in our land; Respect those who have worked to build and develop our country; and Believe that South Africa belongs to all those who live in it, united in our diversity. We therefore, through our freely elected representatives, adopt this Constitution as the supreme law of the Republic so as to - Heal the divisions of the past and establish as society based on democratic 


\section{WHAT IS SOCIAL JUSTICE?}

Social justice is said to be a value that is permeated by equality and fairness. ${ }^{42}$ It is also held that the commitment to achieve social justice requires the law to be loaded in favour of the weak and exposed. ${ }^{43}$ Craig $^{44}$ describes social justice as a framework of political objectives, pursued through social, economic, environmental and political policies, based on an acceptance of difference and diversity, and informed by values concerned with the following: achieving fairness and equality of outcomes and treatment; recognising the dignity and equal worth and encouraging the selfesteem of all; meeting basic needs; maximising the reduction of inequalities in wealth, income and life chances; and the participation of all, including the most disadvantaged.

Indeed, the Marikana people and, in particular, those killed on this fateful day, quite clearly represent the disadvantaged members of our society who are employed in a sector that is seen as the locomotive of South Africa's economic development. ${ }^{45}$ In other words, mining, which drives the economy, as well as those killed in Marikana, and their like, is the force behind this reality. And for what in return for their labour? ${ }^{46}$

It is common cause that the working conditions of mineworkers are physically demanding, risky and are disproportionately disconnected from the occupational risk to which they are exposed on a daily basis. The Marikana incident started with mineworkers' demands for better working conditions through a collective bargaining process. Collective bargaining is the most recognised and effective way of resolving labour disputes between employer and employees, with the latter generally being in a unionised form

values, social justice and fundamental human rights; Lay the foundation for a democratic and open society in which the government is based on the will of the people and every citizen is equally protected by law; Improve the quality of life of all citizens and free the potential of each person; and Build a united and democratic South Africa able to take its rightful place as a sovereign state in the family of nations." See also the equality clause in s 9 of the Constitution.

41 See the purpose statement in Chapter I of the Labour Relations Act, 1995.

42 Van Deventer Management Strategies for Effective Social Justice Practice in Schools (2013) https://dspace.nwu.ac.za/bitstream/handle/10394/8558/Van_Deventer_I_Chapter_7. pdf? (accessed 2019-08-07) 450.

43 Scarman English Law: The New Dimension (1974) 28-29; Nyenthi "Access to Justice in the South African Social Security System: Towards a Conceptual Approach 2013 46(4) De Jure 901916.

44 Craig "Poverty, Social Work and Social Justice" 2002 British Journal of Social Work 322 669-682; O'Brien "Equality and Fairness: Linking Social Justice and Social Work Practice" 2011 Journal of Social Work 112143145.

45 Fedderke and Pirouz "The Role of Mining in the South African Economy" 200034 5(1) South African Journal of Economic and Management Sciences 1; see also www.econrsa.org/system/files/publications/policy_papers.../pp09_interest.pdf (accessed 2019-07-20) 1.

46 It is widely reported that rock drillers at the time of the infamous Lonmin mine strike earned up to R4 000.00 a month, whilst the CEO, lan Farmer, collected pay and bonuses of $£ 1.2 \mathrm{~m}$ the previous year. See http://www.politicsweb.co.za/news-and-analysis/how-much-do-rockdrillers-at-lonmin-really-earn (accessed 2019-08-25). See also Chetty 2016 New Labour Forum 63. 
as a trade union ${ }^{47}$, but even with non-unionised employees in so-called wildcat strikes. ${ }^{48}$ It is regarded as a principal weapon for employees to counterbalance the bargaining strength of the employer. ${ }^{49}$ This is well supported by the existing literature, which also led us to believe that collective bargaining works for the developing labour relations law. ${ }^{50}$

Collective bargaining is said to have been coined in the $18^{\text {th }}$ century by Sidney and Beatrice Webb, mainly to defuse the strength of the employer by means of graduated processes of bargaining with organised employees, beginning with negotiations and progressing to the threat of a strike in the event that parties do not resolve the dispute. In other words, parties negotiate first, and if negotiations fail, employees may embark on a strike. ${ }^{51}$ Kahn notes that the purpose of collective bargaining is to restore social justice. ${ }^{52}$ Collective bargaining is further seen as implying a win-lose situation, whereby labour will not be sold if the price is not right. ${ }^{53}$ Essentially, this wholesale process of bargaining involves power, confrontation and compulsion. Sometimes, the sanity of the intended goal is overtaken by desperation, which leads to employees (wrongly) resorting to violence and other criminal activities as a means to an end. ${ }^{54}$ Rycroft describes this as the tyranny of the mob, which remains an urgent concern, undermining democratic processes and rational negotiation. ${ }^{55}$ This should rather be dealt with through appropriate criminal or civil processes.

\section{THE LEGAL FRAMEWORK FOR COLLECTIVE BARGAINING IN SOUTH AFRICA}

As previously mentioned, collective bargaining is a recognised tool in the labour relations environment to regulate relations between employer and employees. Collective bargaining entails progressive engagements between the employer and employees, with the aim of reaching a collective agreement. It begins with negotiations, which are naturally nonconfrontational, and if concessions cannot be made, a strike is the inevitable course of action. Section 23 of the Constitution sanctions the employees' right to strike as a component of collective bargaining. The right to strike is

47 Du Toit et al Labour Relations Law: A Comprehensive Guide 277.

48 Du Toit et al Labour Relations Law: A Comprehensive Guide 358.

49 Du Toit et al Labour Relations Law: A Comprehensive Guide 277.

50 See the purpose statement in terms of the LRA; Davies Perspectives on Labour Law (2009) 178; Jenkins and Sherman Collective Bargaining (1977) 6; In re Certification of the Constitution of the Republic of South Africa, 19961996 (10) BCLR 1253 par 64.

51 Hutt The Theory of Collective Bargaining (1954) 21; Godfrey Collective Bargaining: The Past, The Present and the Future (2010); s 64 of the LRA.

52 Davies and Freedland Labour and Law (2008) 18.

53 Nel and Van Rooyen Worker Representation in Practice in South Africa (1985) 93; Harrison "Collective Bargaining Within the Labour Relationship: In a South African Context" (2004) https://dspace.nwu.ac.za/bitstream/handle/10394/2409/harrison_ds.pdf?sequence=1 (accessed 2019-09-26) 26.

54 South African Transport and Allied Workers Union v Garvas 2012 (8) BCLR 840 (CC); [2012] 10 BLLR 959 (CC); (2012) 33 ILJ 1593 (CC); 2013 (1) SA 83 (CC).

55 Hepple, Le Roux and Sciarra Laws Against Strikes: The South African Experience in an International and Comparative Perspective (2015) 122 (read online). 
reiterated and given content in terms of the provisions of the LRA. ${ }^{56}$ This section sets out the procedure for a protected strike.

In light of the procedural aspects discussed above, it is clear that the action embarked on by Marikana mineworkers was a strike action. A strike can be either protected or unprotected. In the case of the former, a strike is protected if it complies with section 64 of the LRA or any other procedure set out in terms of a collective agreement that is made between the employer and the trade union representing the employees. If the procedure is not followed, the strike is said to be unprotected, which has various

56 Ss 4, 64 and $187(a)-(c)$ of the LRA. S 64(1) provides: "Every employee has the right to strike and every employer has recourse to lock-out if-

(a) the issue in dispute has been referred to a council or to the Commission as required by this Act, and-

(i) A certificate stating that the dispute remains unresolved has been issued; or

(ii) A period of 30 days, or any extension of the period agreed to between the parties to the dispute, has elapsed since the referral was received by the council or the Commission; and after that-

(b) in the case of a proposed strike, at least 48 hours' notice of the commencement of the strike, in writing, has been given to the employer, unless-

(i) The issue in dispute relates to a collective agreement to be concluded in a council, in which case, notice must have been given to that council; or

(ii) the employer is a member of an employers' organisation that is a party to the dispute, in which case, notice must have been given to that employers' organisation; or

(c) in the case of a proposed lock-out, at least 48 hours' notice of the commencement of the lock-out, in writing, has been given to any trade union that is a party to the dispute, or if there is no such trade union, to the employees, unless the issue in dispute relates to a collective agreement to be concluded in a council, in which case, notice must have been given to that council, or

(d) $\ldots . . . . "$

However, subsection (3) provides that "the requirements of subsection (1) do not apply to a strike or a lock-out if-

(a) the parties to the dispute are members of a council, and the dispute has been dealt with by that council in accordance with its constitution;

(b) the strike or lock-out conforms with the procedures in a collective agreement;

(c) the employees strike in response to a lock-out by their employer that does not comply with the provisions of this Chapter;

(d) the employer locks out its employees in response to their taking part in a strike that does not conform with the provisions of this Chapter; or

(e) the employer fails to comply with requirements of subsections (4) and (5)."

Closely linked to subsection (3) in terms of the restrictions on the employees' exercise of the right to strike are the provisions of section 65(1). In terms of this section, "[n]o person may take part in a strike or lock-out or in any conduct in contemplation or furtherance of a strike or a lock-out if-

(a) that person is bound by a collective agreement that prohibits strike or a lock-out in respect of the issue in dispute;

(b) that person is bound by an agreement that requires the issue in dispute to be referred to arbitration;

(c) the issue in dispute is the one that a party has the right to refer to arbitration or to the Labour Court in terms of the Act;

(d) that person is engaged in-

(i) an essential services; or

(ii) a maintenance service." 
consequences for the participants. Ordinarily, the living law in South Africa would have required the employer to do one of the following: 57

- issue an ultimatum warning employees involved to desist from what they are doing; 58

- issue a threat of dismissal:59

- obtain an interdict; 60 or

- claim just and equitable damages from the employees for not honouring their side of the contract, or locking them out. ${ }^{61}$

Furthermore, the employer retains the power to discipline wrongdoers on an individual basis or as a group. 62 Essentially, an unprotected strike constitutes a potentially dismissible offence. ${ }^{63}$ However, dismissal in relation to an unprotected strike does not follow as a matter of course. Employers are

57 Stuttafords Department Stores Ltd v Southern African Clothing and Textile Workers Union [2001] 1 BLLR 46 (LAC) 658 par 41.

58 Mzeku v Volkswagen SA (Pty) Ltd [2001] 8 BLLR 857 (LAC) par 29. In NUM v Billard Contractors CC [2006] BLLR 1191 (LC), the court held that the purpose of an ultimatum is to provide a cooling-off period before a final decision to dismiss is taken, and that there is a discrete right to be heard after the ultimatum has expired. See also National Union of Metalworkers v Lectropower (Pty) Ltd (2014) 35 ILJ 3205 (LC) par 25; National Union of Mineworkers v Goldfields Security Ltd (1999) 20 ILJ 1553 (LC) 36; Professional Transport Workers Union v Fidelity Security Services (2009) 30 ILJ 1129 (LC) 43; Performing Arts Council of the Transvaal v Paper Printing Wood and Allied Workers Union 1994 (2) SA 204 (A) par 217D and Plaschem (Pty) Ltd v CWIU (1993) 14 ILJ 1000 (LAC) 1006H-I.

59 In terms of Schedule 8 of the LRA (Code of Good Practice: Dismissal) item 6(2) on dismissals and industrial action provides that "the employer should, at the earliest opportunity, contact a trade union official to discuss the course of action it intends to adopt. The employer should issue an ultimatum in clear and unambiguous terms that states what is required of the employees and what sanction will be imposed if they do not comply with the ultimatum. The employees should be allowed sufficient time to reflect on the ultimatum and respond to it, either by complying with it or rejecting it. If the employer cannot reasonably be expected to extend these steps to the employees in question, the employer may dispense with them." See also Mzeku $v$ Volkswagen SA (Pty) Ltd supra; Mondi Paper (a Division of Mondi Ltd) v Paper Printing Wood \& Allied Workers Union (1997) 18 ILJ 84 (D); Eskom Ltd v National Union of Mineworkers (2001) 22 ILJ 618 (W); Sappi Fine Papers (Pty) Ltd Adams Mill v Paper Printing Wood \& Allied Workers Union (1998) 19 ILJ 246 (SE).

$60 \mathrm{~S} 68(1)(a)$ of the LRA.

61 S 68(1) of the LRA. See Du Toit et al Labour Relations Law: A Comprehensive Guide 358-359; Stuttafords Department Stores Ltd v Southern African Clothing and Textile Workers Union supra par 12; Algoa Bus Co v SATAWU [2010] 2 BLLR 149 (LC) par 44. In this case, the court held that just and equitable compensation is not equivalent to all the damages the employer may have suffered as a result of the unprotected strike.

62 CEPPWAWU v Metrofile (Pty) Limited (JA37/01) [2003] ZALAC 22 (19 December 2003) par 27 and 54; Imperial Car Rental (Pty) Ltd (Jet Park) v Transport and General Workers Union (LAC) Transvaal Division case no: NH11/2/22436. See also Moahlodi v East Rand Gold and Uranium Co Ltd (1988) 9 ILJ 597 (IC). In this case, the court formulated the test as follows: "An employer need not be satisfied beyond reasonable doubt that an employee has committed an offence. The test to be applied is whether the employer had reasonable grounds for believing that the employee has committed the offence. It is sufficient if, after making his own investigations, he arrives at a decision on a balance of probabilities, that the offence was committed [by the employee] provided that he affords the employee a fair opportunity of stating his story in refutation of the charge." See item 3(4) of the Code of Good Practice: Dismissal in terms of the LRA.

63 The LRA recognises three grounds of dismissal - namely misconduct, operational requirements or incapacity (s 188(1)(a)). 
warned against a knee-jerk approach when dealing with dismissals following unprotected strikes. ${ }^{64}$ In determining whether to dismiss employees engaged in an unprotected strike, the Act requires consideration of factors such as the reasonableness of the demand or whether employees' action is not in reaction to an injustice on the part of the employer. ${ }^{65}$

Except for counter-productive violence, or lest we be wrongly understood to suggest that the end justified the means in the Marikana context, one should not lose sight of the fact that mineworkers in Marikana were fighting against economic injustice perpetuated by the employer. In addition, the frustration caused by the absent NUM, which failed to show support at this crucial time, should not be discounted.66 Under these circumstances, employees arguably felt it was up to them to take action or direct their own struggle. This may also explain why NUM subsequently lost some of its membership to the Association of Mineworkers and Construction Union (AMCU).

Since there was no court decision on the Marikana incident, relaying and prosecuting what transpired on that fateful day, we have to rely on the findings of the Commission, the rich legal literature at our disposal, and the LRA. The report of the Farlam Commission of Inquiry established that the Marikana workers' action was in contravention of strike law, and hence that their action was unprotected; in the authors' view, it generally fell short of the description of crime ${ }^{67}$ According to this viewpoint, the employees' action did not warrant police force.

\section{THE USE OF A COMMISSION OF INQUIRY TO UNCOVER THE TRUTH}

Commissions of inquiry have become fashionable these days, but unfortunately, their prevalence cannot be linked to many positive results. A

64 Item 6 of Schedule 8 of the Code of Good Practice: Dismissal provides: "(1) Participation in a strike that does not comply with the provisions of Chapter IV is misconduct. However, like any other act of misconduct, it does not always deserve dismissal. The substantive fairness of dismissal in these circumstances must be determined in light of the facts of the case, including-

(a) the seriousness of the contravention of this Act,

(b) attempts made to comply with this Act, and

(c) whether or not the strike was in response to unjustified conduct by the employer.

(2) Prior to dismissal, the employer should, at the earliest opportunity, contact a trade union official to discuss the course of action it intends to adopt. The employer should issue an ultimatum in clear and unambiguous terms that states what is required of the employees and what sanction will be imposed if they do not comply with the ultimatum. The employees should be allowed sufficient time to reflect on the ultimatum and respond to it, either by complying with it or rejecting it. If the employer cannot reasonably be expected to extend these steps to the employees in question, the employer may dispense with them."

65 Item $6(1)(c)$ of Schedule 8 of the LRA; Stuttafords Department Stores Ltd $v$ Southern African Clothing and Textile Workers Union supra.

66 Finnemore Introduction to Labour Relations in South Africa 50; Alexander 2013 Review of African Political Economy 605-619 607.

$67 \mathrm{Ch} 4$ of the Marikana report 53 
classic and most recent example is the Seriti Commission. ${ }^{68}$ There has been general discomfort expressed in recent years about the use of commissions of inquiry and their effectiveness. Questions are being asked about their relevance. Are commissions of inquiry truly aimed at uncovering injustice or do they just record wrongs? Are they simply lame ducks that are costing victims and taxpayers dearly? Do they serve any purpose at all? Are they merely elaborate ruses aimed at distracting the public and delivering outcomes favourable to only a few? Perhaps most importantly, are they an effective use of public resources? ${ }^{69}$ Summing up his observations about commissions of inquiry, Terry Crawford-Browne noted that commissions of inquiry have traditionally become places to park a hot potato until it gets cold. ${ }^{70}$

The authors share the views above and scrutinise the Marikana Commission against this backdrop. The terms of reference in the Commission were, among other things, to "inquire into, make findings, report on and make recommendations concerning" the conduct of Lonmin, the SAPS, AMCU and NUM, the role of the Department of Mineral Resources or any other government entity implicated in the events, and "[t]he conduct of individuals and loose groupings in fermenting and/or otherwise promoting a situation of conflict and confrontation which may have given rise to the tragic incident". ${ }^{71}$

It would appear that one of the witnesses who testified before the Commission, Lieutenant-General Mbombo, mentioned that when she spoke to the then-Minister of Police, he (the latter) had said that the Lonmin executive was calling him and pressurising him. ${ }^{72}$ In this regard, she said that the National Commissioner had asked her the previous evening who the shareholders were, to which she replied that she did not know, but that the Minister had mentioned a businessman and African National Congress (ANC) leader, whereupon the National Commissioner had said that she "got it". ${ }^{73}$

In light of all this, and with police having received a signal to "shoot the bastards" from the then-Minister of Mineral Resources ${ }^{74}$ - a reference to mineworkers, and political pressure being brought to bear on certain individuals - it seems necessary to determine the meaning of the words "putting pressure on someone". The term "to put pressure on some(one)" is an idiom, which simply means "to try to influence or persuade one to do

68 See Corruption Watch $v$ The Arms Procurement Commission (81368/2016) [2019] ZAGPPHC 351, where the court held that the Commission failed to conduct the task assigned to it through its terms of reference and the Constitution in line with the principle of legality (summary).

69 Crawford-Browne "Parking a Hot Potato: Are Commissions of Inquiry (in)effective" (13 August 2013) http://www.enca.com/opinion/parking-hot-potato-are-commissions-inquiryineffective.

70 lbid.

71 The mandate of the Farlam Commission of Inquiry.

72 Marikana Report 163.

73 Marikana Report 163

74 Bruce "Marikana and the Doctrine of Maximum Force" (13 September 2012) www.mampoer.co.za (accessed 2019-07-27) 14. 
something or act a certain way; to make demands on or expect something from someone". 75

The view of the authors is that the statements above are sufficient to justify a further inquiry into the implicated individuals' actions or inactions, given the status, interests and (political) influence that each of them possesses. There is, arguably, no way that Mr Ramaphosa's influence as a government leader and businessperson with interests in Lonmin could have fallen off the Farlam Commission's radar so easily, if the priority was to establish the truth. What exactly was the relevance of knowing who the shareholders were ${ }^{76}$ Furthermore, the statement "to kill bastards" is, first, degrading, and secondly, it dehumanises the affected mineworkers, thereby suggesting that their lives deserved to be taken in such a manner. Besides, incidents such as Marikana (labour unrests) were and still are being experienced in the farming sector, where people are killed or injured. Another example is the \#fees must fall campaign. However, there was not the same reaction from the elite to these cases as to the Marikana tragedy. The personal interests in Lonmin were arguably a factor that prompted the interference and support of the different ministries indicated above. It is submitted that the time has come for laws to be introduced to prevent those with influential roles, such as senior politicians in government, from doing business with the same government that they are serving, for fear of conflicting interests. A mere disclosure of interests is not enough.

Under the circumstances, one would have expected, at the very least, an intervention by the labour ministry, unless the ministry was not aware of all the incidents leading up to the Marikana massacre. This is unlikely, given the attention that this tragic event received, both locally and internationally. The point here is that the labour ministry seems to us to be the most appropriate entity to intervene, where necessary, in labour matters such as this one. In the authors' view, the Commission was a bad horse to ride in pursuit of closure for the Marikana massacre; its ineffectiveness, which is still felt by many today, reinforces this view, as there have still been no consequences. No compensation has been paid to bereft families and no conviction has been made - only apologies from people cleansed by the same Commission. However, it is simple logic that an apology only becomes necessary where something is done wrongfully.

\section{DUTY OF EMPLOYEES TO OBEY LAWFUL AND REASONABLE ORDERS OF THE EMPLOYER}

The duty of subordinates to obey superior orders is inherent to the proper functioning of every organisation, including state institutions. ${ }^{77}$ It is implied in any contract of employment. ${ }^{78}$ However, orders should be given by a

75 The Free Dictionary "Put Pressure On" https://idioms.thefreedictionary.com/put+pressure +on (accessed 2019-09-19).

76 Marikana Report 163.

77 Eden "Criminal Liability and the Defence of Superior Orders" 1991 South African Law Journal 640 .

78 Joubert (ed) The Law of South Africa (LAWSA) Vol 6 (2004) par 66. 
competent person and must be reasonable and lawful; otherwise, an employee cannot be expected to comply with an order, if to do so would break the law. ${ }^{79}$ Collier et al observed:

"an employee may refuse to follow an instruction that contravenes any law or public policy or subjects employee to personal danger. An employee's refusal may furthermore be justified where the instruction falls outside the ambit of the employees' contractual duties." 80

This means that although an employee may refuse to obey unlawful and unreasonable orders without fear of being charged with insubordination, the employer retains the right to dismiss under the circumstances. However, all employees are protected against unfair dismissals. In $R v$ Smit, ${ }^{81}$ the court held that if an order is manifestly unlawful, the subordinate may choose not to obey it; otherwise he or she would be acting unlawfully.

In the case of $S \vee$ Mostert, ${ }^{82}$ the court referred to the American court decision in United States $v$ Calley. ${ }^{83}$ In this case, the court said:

"[A] determination that an order is illegal does not, of itself assign criminal responsibility to the person following the order for acts done in compliance with it ... (such) acts of a subordinate ... are excused and impose no criminal liability upon him unless the superior's order is one which a man of ordinary sense and understanding would, under the circumstances, known to be unlawful, or if the order in question is actually known to the accused to be unlawful."

In Motor Industry Staff Association v Silver Spray Painters \& Panel-Beaters (Pty) $L t d{ }^{84}$ the court outlined the circumstances of an employee that may constitute a valid cause to refuse an order given by an employer. These include the following:

- where the employee is not capable of performing the instruction, as he or she does not have the requisite qualification to attend to the task, which will effectively render the instruction unreasonable;

- where the instruction issued by the employer does not fall within the ambit of the employer's job description and amounts to a unilateral amendment of the employer's contract; and

- where an unreasonable instruction is being issued by the employer.

79 S 199(6) of the Constitution. S 47(1) of the South African Police Services Act provides that subject to subsection (2), a member shall obey any order or instruction given to him or her by a superior or a person who is competent to do so: provided that a member shall not obey a patently unlawful order or instruction. See also Collier, Fergus, Cohen, Du Plessis, Godfrey, Le Roux and Singlee Labour Law in South Africa: Context and Principles (2018) 131; Burchell and Hunt South African Criminal Law \& Procedure Vol I (1997) 108-9.

80 Collier et al Labour Law in South Africa 131.

81 (1900) 17 SC 561. See S v Banda 1990 (3) SA 466 (B); Brassey, Cameron, Cheadle and Olivier The New Labour Law: Strikes, Dismissals, and the Unfair Labour Practice in South African Law (1987) 430-432.

82 (AR 842/03) [2005] ZAKZHC 27; [2006] 4 All SA 83 (N) (8 March 2005) 6.

83 (1973) 22 USMCA 534 (US Court of Military Appeals); S v Banda supra 494F-G.

84 (2013) 34 ILJ 1440 (LAC) par 32. 
The guidelines for the use of lethal force are well regulated in terms of the Criminal Procedure Act, ${ }^{85}$ of which any police official should reasonably be assumed to have knowledge. In terms of section 49 of the Criminal Procedure Act, use of force by the police should be proportional to the threat that is faced. It is public knowledge that automatic rifles were used in the Marikana case, and that most victims were shot at close range and in their backs, an act that suggests that they were no longer a threat to police, as the victims were running away from the police. ${ }^{86}$

\section{CONCLUSION AND RECOMMENDATIONS}

As demonstrated in the discussion above, the Marikana massacre could have been avoided if the deliberate interference and sheer disrespect of the rule of law by all stakeholders had not been allowed. Similarly, good faith bargaining on the part of both employer and trade union representatives, and between the latter and its own membership, could have played an important role in easing the tension between the bargaining parties and, by extension, facilitated the bargaining process. Lawmakers should consider incorporating good-faith bargaining into the law, as this would, in all probability, enable parties involved in collective bargaining to commit to the aims and aspirations of their constituency (membership), informed by the truth, reasons and relative dynamics associated with the circumstances. The opposite will not work. The National Union of Mineworkers provides a good example. ${ }^{87}$ The frustration among employees in the case of Marikana was that NUM traded off its members' loyalty to maintain its cosy friendship with the management for purposes of self-aggrandisement. 88 The members of NUM may therefore sue the trade union for damages. ${ }^{89}$

85 S 7 of Act 122 of 1998 , as amended.

86 Alexander 2013 Review of African Political Economy 605-619 607 www.tandfonline.com/doi/abs/10.1080/03056244.2013.860893 (accessed 2019-09-25) 608; Finnemore Introduction to Labour Relations in South Africa 50.

87 The NUM union officials and shop stewards had clearly lost touch completely with their membership and allegedly become too close to management who paid their salaries and provided them with many perks such as cars and cell phones (see Marinovich "Conflict of Interest, Inc: Mining Unions' Leaders Were Representing Their Members While in Corporations' Pay" (24 April 2013) https://www.dailymaverick.co.za/article/2013-04-24conflict-of-interest-inc-mining-unions-leaders-were-representing-their-members-while-incorporations-pay/ (accessed 2017-06-11)). See also Harvey "Marikana as a Tipping Point? The Political Economy of Labour Tensions in South Africa's Mining Industry and How Best to Resolve Them" (2013) South African Institute of International Affairs Occasional Paper NO 16417.

88 It is public knowledge that mineworkers were (and still are) exploited and living in squalor, and that nothing was done by either the government (as the highest body in terms of policy making in the country) or NUM (as the then-majority trade union in the sector). Instead, the latter chose to detach itself from the cause to liberate employees from economic enslavement at the altar of self-aggrandisement. See also Peter, Lekgowa, Mmope, Sinwell and Xezwi "Marikana: A View From the Mountain and a Case to Answer" 143-5 https://www.researchgate.net/publication/339043292_MARIKANA_A_View_from_the_Moun tain and a Case to Answer (accessed 2017-07-21) 16.

$89 S A \bar{M} W U$ v Jada (2003) 24 ILJ 1344 (W); FAWU v Ngcobo NO [2013] 12 BLLR 1171 (CC). 
The use of the SAPS to supervise the collective bargaining process, as happened in the Marikana case, should be discouraged in the most emphatic possible terms. The Marikana Report revealed that there had been a mishandling of certain information by the police, ${ }^{90}$ people whose sole responsibility is to ensure the safety and protection of the community they serve. ${ }^{91}$ According to the Marikana Report, a memory stick containing 'top secret information' was lost between the police and could not be presented to commission for examination. For a successful investigation, the collection of data is critical. In the authors' view, determined police would not wish to lose the collected data (especially for a sensitive case such as Marikana); otherwise they would not, in the authors' view, be on the SAPS' payroll. Their conduct in Marikana amounts to an obstruction of justice. In line with this, it is the authors' view that a private investigation be considered, first with regard to the police's conduct, and secondly, into all people whose names were highlighted in the Marikana report. This view is premised on the fact that police cannot be used to investigate themselves or their own conduct, since the results would be questioned from a credibility perspective. In addition, there is a serious need to subject our police to further training on issues related to Marikana, such as crowd control and the like.

Furthermore, trade unions (and officials alike) require further training to conscientise them about their responsibilities and roles when they assume union positions. Webb ${ }^{92}$ stated that a trade union is a continuous association of wage earners having the purpose of maintaining or improving the conditions of their working lives, and not those of anyone else. The guidelines drawn up by NEDLAC, which are used when considering the applications for registration of trade unions, also warned against what is called "sweetheart unions", requiring instead that unions be genuine and independent. ${ }^{93}$ Cohen et al took this point even further when they observed that trade unions owe a duty of care (in the same way that directors of companies do) to their members, and can be held liable in delict if they breach this duty. ${ }^{94}$ In line with this observation, it is suggested that NUM should be made accountable to its constituency for the lacklustre performance it displayed in the period leading up to and during the Marikana incident.

\footnotetext{
Marikana Report 452 par 74

S 205 of the Constitution.

92 Sidney and Beatrice Webb quoted in Green Industrial Relations 2ed (1985) 10-12. See the definition by Sydney and Beatrice Webb in Bendix Industrial Relations in South Africa 5ed (2010) 161; see Encyclopaedia Britannica Vol 3554.

$93 \mathrm{~S} 95$ of the LRA; Municipal and Allied Trade Union of South Africa (MATUSA) v Crouse N.O [2015] 11 BLLR 1172 (LC); (2015) 36 ILJ 3122 (LC) par 13.

94 Cohen, Rycroft and Whitcher Trade Unions and the Law in South Africa (2009) 83: Manamela The Social Responsibility of South African Trade Unions: Labour Law Perspective (doctoral dissertation, University of South Africa) 2015 uir.unisa.ac.za/bitstream/handle/10500/20069/thesis_manamela_me.pdf?sequence $=1$ (accessed 2019-09-11) 16; Du Toit et al Labour Relations Law: A Comprehensive Guide 243.
} 
Finally, the crafting of a rule to regulate state officials (those with power, influence, access and control over state funds by virtue of their occupations) in their business intercourse with the government or its institutions is long overdue. This should put them in the same position as directors of companies who, in terms of the principle regulating insider information (trading), cannot take advantage of being privy to sensitive information to compete in business opportunities created by the same market or organisation, as this would constitute unfair dealing. ${ }^{95}$ This, in the authors' view, will help deter conflicted people who are often powerful politically, economically and otherwise, from having or enjoying an unfair advantage over others.

Many years have passed since the Marikana massacre, and affected communities have yet to see or experience justice in action. Fortunately, or unfortunately, a turnaround from this state of affairs depends largely on political will. Perhaps a leaf can be taken from how the Life Esidimeni Arbitration unfolded under retired former Deputy Chief Justice of the Constitutional Court Moseneke. ${ }^{96}$ Interestingly, Marikana victims were breadwinners whose families relied solely on their small income, and their deaths amounted to terminating a source of living for their families. However, the Commission did not reach a resolute decision on the issue of compensating the victims' families. ${ }^{97}$ Like the Seriti Commission, the Marikana Commission has been yet another distinct flop. Resources were not optimally used.

95 Cassim, Cassim, Cassim, Jooste, Shev and Yeats Contemporary Company Law (2011) 833 and 839; 72 of the Securities Services Act 36 of 2004.

96 The Life Esidimeni Arbitration was established following Recommendation 17 of the Health Ombudsperson's "Report into the circumstances surrounding the deaths of about 144 mentally ill patients at Life Esidimeni Health Facility: Gauteng Province" (Ombud's Report). See In the Arbitration Between: Families of Mental Health Care Users Affected by the Gauteng Mental Marathon Project and National Minister of Health of the Republic of South Africa www.saflii.org/images/LifeEsidimeniArbitrationAward.pdf (accessed 2020-12-21).

97 Marikana Report 518-520. 